University of Nebraska - Lincoln

DigitalCommons@University of Nebraska - Lincoln

Sociology Department, Faculty Publications

Sociology, Department of

$12-1976$

\title{
On Political Tolerance: Comments on "Origins of Tolerance"
}

Harry J. Crockett

University of Nebraska-Lincoln

Follow this and additional works at: https://digitalcommons.unl.edu/sociologyfacpub

Part of the Sociology Commons

Crockett, Harry J., "On Political Tolerance: Comments on "Origins of Tolerance"'" (1976). Sociology Department, Faculty Publications. 124.

https://digitalcommons.unl.edu/sociologyfacpub/124

This Article is brought to you for free and open access by the Sociology, Department of at DigitalCommons@University of Nebraska - Lincoln. It has been accepted for inclusion in Sociology Department, Faculty Publications by an authorized administrator of DigitalCommons@University of Nebraska - Lincoln. 


\title{
On Political Tolerance: Comments on "Origins of Tolerance"
}

\author{
H A R R Y J. C R O C K E T T, J R., University of Nebraska-Lincoln
}

The continued scalability of a set of attitude items used in national sample surveys separated by 19 years is a remarkable and useful result. In a discipline lacking valid measures of socially important attitudes, such an outcome merits close study and wide dissemination. But exhibiting the stability of Stouffer's tolerance scale is not the prime end of the Williams et al. paper; they pursue an accounting of the "origins of tolerance." Nor is it the prime interest of the larger research from which their paper arises. Our concern in the larger study is with the political tolerance of the American people, their willingness to practice the democratic restraint shown by Lipset and $\mathrm{Raab}^{1}$ to be central to democracy in America. We are studying the conditions under which democratic restraint prospers or declines, and the changes over time in these attitudes and propensities. In my judgment, the paper by Williams et al. establishes the reliability of Stouffer's tolerance scale in 1954 and 1973 , but it seriously distorts rather than illuminates understanding of political tolerance. $^{2}$

The reader will recall that the Williams et al. strategy is to set the Stouffer tolerance scale as the dependent variable in a multiple regression analysis using various measures of exposure to diversity as independent variables. The multiple classification analysis routine they employ isolates the relationship between each independent variable and the dependent variable when effects of all the other variables are statistically controlled. Finding statistically significant associations for all relationships except those involving the male-female variable, the authors conclude that increasing diversity in American life is leading to marked increases in tolerance. I find this conclusion seriously misleading for two kinds of reasons. The conclusion is reached by a mechanical manipulation of variables which are given no conceptual substance. Second, the dependent variable, Stouffer's tolerance scale, does not capture nearly enough of the complex meaning of political tolerance in the United States.

To illustrate the conceptual barrenness of their analysis, I will focus on their treatment of education, which both they and I consider the most important single source of political tolerance in the United States. Why should level of education promote tolerance? The authors address this basic question in one paragraph consisting of three sentences. ${ }^{3}$ One can't regard brief mention of Stouffer's 1955 views and a tiny scattering of later research (presented as supporting those views) as advancing understanding. The authors acknowledge in a footnote that there may be some question of the meaning of the observed relationship between education level and political tolerance, citing a paper by Robert Jackman in this regard. Unfortunately, the paper by Robert Jackman deals only secondarily with the meaning of the positive relationship between education level and tolerance; it is rather an 
important paper by Mary Jackman—ignored by the authors-which argues in detail that relationships between education level and diverse attitudes (such as political tolerance) when measured with an "agree-disagree" format are best considered artifactual rather than substantive. Of course, the questions raised by either of the Jackmans do not come close to exhausting the matter; in a manuscript chapter exceeding three-dozen pages, I have been able to establish no more than an adequate-surely not an exhaustive-account of the meaning of education for political tolerance.

In a classic critique of Stouffer's work published in 1955, Glazer and Lipset pointed out that changes in the political climate may have more to do with changes in tolerant attitudes than increases in the education level among the population. They cited the greater intolerance of the 1950's as compared with the 1930s as a case in point; though the education level in the population had advanced, political tolerance had constricted due to a political climate of concern over the issue of Communism. Herbert Hyman reached a similar conclusion from his comparative study of British and American reactions to the alarums of the 1950s: the reactions in the two societies were distinguished not by the "great social, economic, and technological forces" posited by Stouffer (and reaffirmed by Williams et al.) but rather by specific differences in political climates. Indeed, Stouffer himself predicted that a decline in fear of Communism would be accompanied by a rise in political tolerance. I believe, along with Glazer, Lipset, Hyman, and Stouffer, that the nature of the political climate must be considered in assessing levels of political tolerance at different points in time or between one society and another. Certainly it is not credible to reach conclusions regarding changes in political tolerance without any assessing of the effects of changes in political climates-yet this is the procedure followed by Williams, Nunn, and St. Peter.

When the issue of Communism as it might affect political tolerance is considered, the strong impact of political climate on tolerance is disclosed. Though space limits permit but one illustration, the data of Table 1 provide only one example among many in our research weighing against the Williams et al. conclusion. To appreciate the information in Table 1, it must be stressed that in both 1954 and 1973 average education levels among persons scoring in the two highest categories of Stouffer's tolerance scale are much higher than for persons scoring in the lower scale categories. Yet the politically tolerant response (i.e., designating the reporting of suspected Communists to the FBI to be a "bad idea'") is chosen by a majority of these relatively highly educated persons only among those who also view the threat of Communism as slight. Reviewing these data and many more elsewhere, I concluded that " although we need not go so far as Hyman in attributing changes in political tolerance exclusively to contemporaneous factors in the political situation, our present evidence agrees with him and with Glazer and Lipset in finding the political climate an important factor in determining levels of democratic restraint. A twofold conclusion seems prudent: at a given level of threat, a more highly educated population will be more politically tolerant than a less-educated population; at the same time, increases in the educational level of a population will 
Table 1. PERCEPTION OF COMMUNIST THREAT, AND DISPOSITION TO REPORT SUSPECTED COMMUNISTS TO THE FBI IN 1954 AND 1973, AMONG PERSONS HIGH IN TOLERANCE SCALE SCORE

\begin{tabular}{|c|c|c|c|c|c|}
\hline \multirow{2}{*}{$\begin{array}{l}\text { Perception } \\
\text { of Communist } \\
\text { Threat }\end{array}$} & \multirow[b]{2}{*}{$\begin{array}{l}\text { Tolerance } \\
\text { Scale Score }\end{array}$} & \multicolumn{3}{|c|}{ Percent Answering } & \multirow[b]{2}{*}{$N$} \\
\hline & & $\begin{array}{l}\text { Good } \\
\text { Idea }\end{array}$ & $\begin{array}{l}\text { Bad } \\
\text { Idea }\end{array}$ & $\begin{array}{l}\text { Don't } \\
\text { Know }\end{array}$ & \\
\hline & \multicolumn{5}{|c|}{1954} \\
\hline Low & High & 46 & 54 & & 232 \\
\hline Middle & High & 60 & 40 & & 647 \\
\hline \multirow[t]{2}{*}{ High } & High & 70 & 30 & & 499 \\
\hline & \multicolumn{5}{|c|}{1973} \\
\hline Low & High & 28 & 64 & 8 & 708 \\
\hline Middle & High & 51 & 41 & 8 & 682 \\
\hline High & High & 67 & 25 & 8 & 382 \\
\hline
\end{tabular}

not produce sharp increases in political tolerance if the perception of internal danger (as, for example, from Communism) among the population is widespread., 4

The data of Table 1 also bring sharply into question the authors' exclusive use of Stouffer's tolerance scale to measure political tolerance. While the scale is admittedly useful for this purpose, it is obviously quite misleading to use it as the sole indicator of political tolerance. The authors conclude that the moderate (though statistically significant) correlations between the tolerance scale and 7 other attitude items (see their note 6) provide strong support for the exclusive use of the tolerance scale to measure political tolerance. In light of the data in Table 1 (and many similar data), my conclusion is that such moderate correlations might just as well be considered evidence for using a variety of indicators. Similarly, the authors claim, on the basis of their finding that a factor analysis of the tolerance scale and the 7 other items mentioned above yields only one factor, that it is "reasonable to assert that the underlying factor is a measure of tolerance and that the scale of willingness to tolerate nonconformists may be generalized to nonconformists not specifically mentioned in the items which compose it." My contention is that their finding of only one factor supplies no basis per se for using the tolerance scale as though it were an adequate, exclusive measure of political tolerance (see, for example, Harmon, Chapter 6 and particularly p. 109). ${ }^{5}$

These brief comments have already overrun the space so generously made available to me. Though I may not have convinced the reader of the tenability of my position, I hope at least to have alerted her or him to the serious misunderstandings of political tolerance which I perceive in the Williams et al. paper.

\section{NOTES}

1. The essence of our study of political tolerance and intolerance is captured by Lipset and Raab's concept of "democratic restraint": "That quality which is missing as democratic commitment diminishes 


\section{2 / Social Forces / vol. 55:2, december 1976}

is a quality of restraint. That is, after all, the nature of the democratic process itself; the Bill of Rights is couched in the language of restraint: Congress shall make no law which abridges the basic freedoms, the right to bear arms shall not be infringed, the security of the home shall not be violated, and so forth. . . . It is democratic restraint which is identified with that aspect of freedom generally called the democratic process, pluralism, civil liberties', (433).

2. As background for these judgments, it is useful to sketch the context of the dispute between my research associates and myself. My view has been from the beginning of our work that an adequate presentation and accounting of the main thrust of our study could not be accomplished within the cramped space of a journal article but required the extended treatment possible in a research monograph. In the interests of maintaining harmony among our research group, though, I did participate as a coauthor of an earlier version of the present Williams et al. paper, a version which was rejected by another journal. Following the rejection of the earlier paper, the more intensively I studied the literature on political tolerance in the United States, and the more I pondered our study materials, the more certain I became that the main thrust of our work required extended treatment in monograph form. Having reached this judgment far in advance of the submission of the paper ultimately published in Social Forces, I advised my research associates that I would have to refuse co-authorship and requested that they footnote my disclaimer on the general grounds that "there is a better way to analyze and interpret the data." But it seemed more useful, professionally, to explain the bases of my judgments in this brief statement.

3. The paragraph reads: "Stouffer's major point regarding education is that young people are likely to be exposed to values different from those learned in the home. He suggests that a lessening of authoritarian rigidity in the classroom has resulted in a system which challenges tradition and stimulates independence of thought. Recent research, within a comparative framework, does show that education in the United States emphasizes cognitive skills as opposed to rote learning (cf. Simpson). Herriott and Hodgkins report that American schools increased both in size and complexity between 1930 and 1970, and several studies have found that the political and social awareness derived through education promotes values consistent with a tolerant attitude (cf. Campbell et al.; McClosky; Nunn; Prothro and Grigg). 4. This is quoted from my chapter, "Education and Political Tolerance,'” prepared for a forthcoming monograph by Clyde Z. Nunn, Harry J. Crockett, Jr., and J. Allen Williams, Jr..

5. I am indebted to Dr. Frank J. Dudek of the University of Nebraska-Lincoln Department of Psychology for this citation.

\section{REFERENCES}

Glazer, N., and S. M. Lipset. 1955. "The Polls on Communism and Conformity.” In Daniel Bell (ed.) The New American Right. New York: Criterion Books.

Harmon, Harry H. 1967. Modern Factor Analysis. Chicago: Uniiversity of Chicago Press.

Hyman, H. H. 1963. "England and America: Climates of Tolerance and Intolerance." In Daniel Bell (ed.) The Radical Right. New York: Doubleday.

Jackman, M. 1973. "Education and Prejudice or Education and Response-Set?' American Sociological Review 38(June):327-39.

Jackman, R. W. 1972. "Political Elites, Mass Publics, and Support for Democratic Principles.' Journal of Politics 34(August):753-73,

Lipset, Seymour Martin, and Earl Raab. 1970. The Politics of Unreason: Right-Wing Extremism in America, 1790-1970. New York: Harper \& Row.

Williams, J. A., Jr., C. Z. Nunn, and L. St. Peter. 1976. "Origins of Tolerance: Findings From a Replication of Stouffer's Communism, Conformity, and Civil Liberties.' Social Forces 55(December):394-408. 